\title{
PERAN PAKUBUWONO X \\ DALAM PEGEMBANGAN DAKWAH ISLAM DI SURAKARTA 1893-1939 \\ Mulyanto
}

Fakultas Dakwah, Insitut Agama Islam Mamba'ul Ulum Surakarta

Mulyanto8000@yahoo.com

\begin{abstract}
The Role of Pakubuwana X in the Development of Islamic Da'wah in Surakarta 1893-1939 was inseparable from the socio-political dynamics that occurred, where the Dutch East Indies Government changed its policy from power expansion to ethical politics or commonly known as the politics of reciprocation. As a result, zending schools were born that carried out the Christian mission in the educational institution.

Pakubuwana $\mathrm{X}$ as the King who has the title Sayidin Panotogomo, the position as the highest leader of the Islamic religion feels objected if his people embrace another. He was not happy with the establishment of zending-run schools in the Surakarta area that carried a Christian mission. Therefore, among the efforts to fortify its people from the spread of Christianity by establishing Mambaul Ulum.

The focus of research is to determine The Role of Pakubuwana X in The Development of Islamic Da'wah in Surakarta in 1893-1939. This research is a qualitative type, namely research that intends to understand the phenomena experienced by the research subjects by examining various phenomena that occurred during the reign of Pakubuwana X.

With the descriptive method, which is a method of examining the status of a group of humans, an object to provide a systematic, factual and accurate picture of the facts and phenomena being studied. From this it can be described The Role of Pakubuwana X in The Development of Islamic Da'wah in Surakarta in 1893-1939 and various related factors and indicators that support the development of this da'wah.

From the results of this study it can be concluded that The Role of Pakubuwana $\mathrm{X}$ in The Development of Islamic Da'wah in Surakarta in 1893-1939 is very large. This can be seen from the increasing number of syi'ar Islam. Kauman is the center of Islamic activity. Various religious activities such as recitation, Islamic schools and major Islamic events continue and still exist.

The rise of syi'ar Islam can also be seen from the increase in the number of people praying in congregation at Masjid Agung, for example, Friday prayers, Dhuhur and Ashr, the number of congregations is getting more and more crowded. Khutbah Jum'at were translated into Javanese and Arabic, previously Khutbah Jum'at used Arabic, installed loudspeakers and broadcast directly by SRI radio (Broadcast Radio Indonesia) belonging to Kasunanan Surakarta.
\end{abstract}

Keywords: Pakubuwana X, Syi'ar, Dakwah

\section{PENDAHULUAN}

Pemerintah Indonesia melalui Presiden Republik Indonesia ke-6, Susilo Bambang Yudhoyono bertempat di Istana Negara pada hari Selasa tanggal 8 November 2011 menetapkan Paku Buwono X sebagai Pahlawan Nasional. Salah satu alasan penetapan tersebut adalah jasanya dalam bidang pendidikan yaitu sebagai pelopor pendidikan rakyat. Selain itu Paku Buwono X juga dianggap berperan aktif dalam perjuangan pergerakan 
nasional, pelopor pembangunan sosial ekonomi, pembentukan jati diri bangsa, dan berperan dalam integrasi nasional. ${ }^{1}$

Pakubuwana X memiliki nama lengkap Raden Mas Sayiddin Malikul Kusno. Lahir hari Kamis Legi, jam 7 pagi tanggal 22 Rajab 1795 (tahun Jawa) atau tanggal 29 November 1866. Ibunya bernama KRAy Kustiyah yang menjadi permaisuri Pakubuwana IX. Pada tanggal 4 Oktober 1869 saat usianya 3 tahun, Pakubuwana X dinobatkan sebagai putra mahkota dengan gelar Kanjeng Gusti Pangeran Adipati Anom Hamangkunegara Sudibya Rajaputra Narendra ing Mataram VI. ${ }^{2}$

Sayiddin Malikul Kusno naik tahta sebagai Pakubuwana X pada tanggal 30 Maret1893 dengan gelar Sampeyandalem Ingkang Sinuhun Kanjeng Sunan Pakubuwana Senopati Ing Ngalogo Ngabdurahman Sayidin Panotogomo Ingkang Jumeneng Kaping Sadasa Ing Nagari Surakarta Hadiningrat. ${ }^{3}$

Dengan kata lain, Pakubuwana X naik tahta pada usia 27 tahun dan memerintah selama 46 tahun dari tahun 1893 sampai tahun 1939. Pakubuwana X meninggal pada usia 73 tahun tepatnya tanggal 20 Pebruari 1939.

Pada awal kekuasaannya terjadi perubahan besar kebijakan politik Pemerintah Hindia Belanda dari ekspansi kekuasaan, berubah dengan menerapkan politik etis atau biasa dikenal dengan politik balas budi. Dampak politik etis tersebut, Belanda mendirikan sekolah-sekolah baru sekolah-sekolah baru yang semuanya lebih untuk kepentingan penjajahan Belanda daripada untuk memajukan rakyat pribumi. Selain itu juga mulai lahir sekolah-sekolah zending ${ }^{4}$ yang merupakan sekolah misi Kristen dalam bidang pendidikan dan juga sekolahsekolah etnis Cina di luar sekolah Belanda tersebut.

Keterlibatan misi Kristen dalam dunia pendidikan sudah ada sejak zaman VOC pada abad ke-17 dan 18. Gereja Kristen Belanda sudah terlibat aktif dalam penyediaan lembaga pendidikan bagi orangorang lokal (Inlands Onderwijs). Bagi kalangan gereja dan gerakan misionaris, sekolah menjadi media efektif untuk penyebaran agama, apalagi jika sekolah tersebut dilengkapi dengan berbagai fasilitas pendidikan modern dan menjanjikan pekerjaan yang lebih baik. ${ }^{5}$

Meskipun jumlah pemeluk Kristen hanya satu persen dari seluruh populasi pada tahun 1900, di beberapa wilayah seperti Maluku, Sulawesi Utara, Nusa Tenggara Timur, Sumatera Utara dan sebagian Kalimantan serta Irian jaya, menurut Arief Subhan mengutip pendapat Gavin Jones, jumlah mereka terus mengalami peningkatan, meskipun tidak menyebutkan secara eksplisit jumlahnya. ${ }^{6}$

Sebagai contoh perkembangan sekolah zending, Sekolah Kelas Dua pada tahun 1903 di Jawa dan Madura terdapat 245 sekolah dan 326 swasta. Di antara yang berstatus swasta tersebut, 63 sekolah berasal dari aktivitas zending. Pada tahun 1900-an jumlah sekolah dari berbagai tingkatan yang diprakarsai oleh misi Kristen sebanyak 541 buah tersebar di berbagai

\footnotetext{
${ }^{1}$ http://www.antaranews.com/berita/141197/lima-alasan-paku-buwono-X-itu-pahlawan; _ lihat pula, http://www.kerajaannusantara.com/id/surakarta-hadiningrat/news/401-Sri-Susuhunan-Pakubuwono-X-

Mendapat-Gelar-Pahlawan-Nasional di akses tanggal 15 April 2021.

${ }^{2}$ Gunawan Sumodiningrat, Ari Wulandari, Paku Buwono X, 46 Tahun Berkuasa di Tanah Jawa,Yogyakarta: Narasi, 2014, hlm. 14. Lihat;https://id.wikipedia.org/wiki/Pakubuwana_X. Lihat pula: Kuntowidjoyo, Raja Priyayi Dan Kawula, Yogyakarta: Ombak, 2006, hlm. 20.

${ }^{3}$ Purwadi, dkk, Sri Susuhunan Paku Buwono X, Perjuangan, Jasa dan Pengabdiannya Untuk Bangsa, Jakarta: Bangun Jasa, 2009, hlm. 7.

${ }^{4}$ Zending menurut Kamus Besar Bahasa Indonesia (KBBI) adalah pekabaran Injil; usaha-usaha menyebarkan agama Kristen atau adan-badan penyelenggara (misi) penyebaran agama Kristen. Lihat: https://kbbi.web.id/zending, di akses tanggal 15 April 2021.

${ }^{5}$ Arief Subhan, Lembaga Pendidikan Islam Indonesia Abad ke-20, Jakarta: UIN Jakarta, 2009, hlm. 88.

${ }^{6}$ Arief Subhan, Lembaga Pendidikan, hlm. 88.
} 
wilayah Indonesia, mayoritas lembaga pendidikan tersebut terletak di wilayah Sulawesi Utara dan Sumatera Utara.

Berkenaan dengan sekolah-sekolah zending tersebut, Snouck Hungronje sebenarnya tidak setuju, karena khawatir akan timbul penolakan dan perlawanan dari rakyat Indonesia. Snouck menulis: "Yang kadang-kadang saya katakan ialah, sesuai dengan banyak utusan Injil (zendeling) dan kawan-kawan zending yang bebas dari sangkaan, ialah pendapat saya tentang harapan yang tidak baik untuk zending Kristen di negara-negara Islam, tidak pernah dengan maksud untuk mendesak, supaya mereka yang merasa diri terpanggil melakukan pekerjaan zending, menghentikan pekerjaan tersebut". ${ }^{7}$

Selain munculnya sekolah-sekolah zending, juga lahir sekolah-sekolah etnis Cina seperti THHK (Tiong Hoa Hwe Koan), sebuah lembaga pendidikan khusus anak-anak Cina di Indonesia. Identitas kecinaan menjadi basis utama organisasi ini. Karena itu, sekolah ini mengimpor kurikulum, buku-buku teks, dan guru dari Cina dan Singapura dengan konfusianisme dan budaya Cina sebagai unsur utama pembelajaran. Sekolah ini mengalami perkembangan pesat dari hanya satu buah pada tahun 1901 menjadi 541 pada tahun 1908 yang tersebar di seluruh wilayah Jawa. Dalam tempo kurang dari satu dasawarsa, komunitas Cina di Indonesia memiliki lebih dari 500 lembaga pendidikan yang didasarkan kepada identitas etnis. ${ }^{8}$

Maraknya sekolah zending dan sekolah Cina, serta cengkeraman yang kuat pemerintah Hindia Belanda terhadap pendidikan Islam, Belanda juga mengeluarkan kebijakan yang diskriminatif dimana mewajibkan setiap guru agama Islam harus mendapatkan ijin sebelum melaksanakan tugasnya sebagai guru agama Islam. Kebijakan ini terkenal dengan ordonansi guru tahun $1905 .^{9}$

Melihat kondisi tersebut, Pakubuwana X sebagai panatagama pada pada tanggal 23 Juli 1905 mendirikan madrasah Mambaul Ulum bertempat di Pawestren Masjid Agung Surakarta. Ada beberapa faktor yang melatarbelakangi Paku Buwono X mendirikan Mambaul Ulum.

Pertama; Kedudukan Paku Buwono X sebagai Panatagama atau pemimpin tertinggi agama Islam. Sebagai Panatagama ia berkeberatan kalau rakyatnya memeluk selain agama Islam. Ia kurang senang terhadap pendirian sekolah-sekolah yang dikelola zending di wilayah Surakarta. Karena itu pendirian Mambaul Ulum sebagai salah satu usaha untuk mengatasi perkembangan agama Kristen di wilayah Kasunanan Surakarta. ${ }^{10}$

Kedua; Adanya mordenisasi sistem pendidikan Islam yang berpengaruh terhadap perubahan sistem pendidikan. Karena itu, sekolah ini sebagai pelopor berdirinya sekolah Islam pertama di Surakarta yang membawa perubahan bagi pendidikan Islam yang semula dari lingkup pesantren beralih ke madrasah dan kemudian menjadi sekolah Islam. Karena itu, di Mambaul Ulum tidak hanya diajarkan materi-materi agama Islam, tetapi juga diajarkan materi-materi lainnya seperti bahasa Jawa, bahasa Melayu, berhitung, ilmu kodrat (Ilmu Pengetahuan Alam) dan beberapa mata pelajaran lainnya. ${ }^{11}$

Ketiga; Kesadaran adanya sumber daya manusia yang berdasarkan nilai-nilai Islam yang menuntut tersedianya pejabat-pejabat agama dan ulama yang cakap dan ahli dibidangnya. Madrasah Mambaul Ulum berperan dalam pemenuhan kebutuhan akan pejabat

\footnotetext{
${ }^{7}$ Surat Snouck Hurgrounje kepada Tuan Lindenborn, surat kiriman dalam de Nieuwe Rtterdamsche Courant tanggal 20 Mei 1915. (Kumpulan Karangan Snouck Hurgronje X, Jakarta: INIS, 1994),hlm. 165-166.

${ }^{8}$ Arief Subhan, Lembaga Pendidikan, hlm. 88.

${ }^{9}$ Abd.Halim Soebahar, KebijakanPendidikan Islam dari Ordonansi Guru sampai UU Sisdiknas, Jakarta: Rajagrafindo, 2013, hlm. 17.

${ }^{10}$ Kuntowidjoyo, Raja Priyayi Dan Kawula, Yogyakarta: Ombak, 2006, cet. 2 hlm. 40-41.

${ }^{11}$ Darsiti Soeratman, Kehidupan Dunia Kraton Surakarta 1830 - 1939, Yogyakarta: Taman Siswa, 1989, hlm. 102.
} 
agama dan ulama. Pemenuhan akan pejabat keagamaan merupakan kebutuhan jangka pendek, sedangkan kebutuhan jangka panjangnya adalah mencetak kader-kader ulama. ${ }^{12}$

Berdirinya Madrasah Mambaul Ulum menjadi fenomenal saat cengkeraman Belanda begitu kuat, termasuk dalam bidang pendidikan. Apalagi pendidikan berbasis Islam yang dalam pandangan Pemerintah Belanda identik menimbulkan semangat anti Belanda. Karena itu, adanya larangan pengajaran Islam di sekolah-sekolah yang diselenggarakan pemerintah atau swasta. Berdirinya Mambaul Ulum tersebut sebagai bentuk keberanian Paku Buwana X sekaligus sebuah simbol perlawanan terhadap pemerintah Hindia Belanda. ${ }^{13}$

Mambaul Ulum adalah lembaga pendidikan Islam formal tertua di lingkungan Kasultanan Surakarta. Semua lembaga pendidikan kasultanan Surakarta saat itu mengambil bentuk pesantren, sedangkan Mambaul Ulum merupakan pendidikan resmi yang dikelola pemerintah dan dibiayai oleh pemerintah Kasultanan Surakarta. Sebuah pendidikan yang menjadi peralihan dari bentuk pesantren ke bentuk madrasah.

Nama Mambaul Ulum berarti sumber ilmu pengetahuan. Ini menjadi harapan

didirikannya pendidikan tersebut. Siapa yang haus ilmu pengetahuan hendaklah minum air sumber ilmu dalam Mambaul Ulum. Mambaul Ulum secara resmi didirikan pada hari Ahad, 20 Jumadil Awal tahun Alip 1835 (Tahun Jawa) atau bertepatan dengan tanggal 23 Juli 1905.

Mambaul Ulum adalah sekolah Islam yang menggunakan sistem klasikal yang mengalami perubahan bentuk dari sistem pondok pesantren ke sistem sekolah Islam yang disebut madrasah. Madrasah Mambaul Ulum merupakan pelopor dalam pembaharuan pendidikan di Surakarta karena dalam materi pelajarannya memasukkan beberapan unsurunsur pendidikan barat ke dalam pendidikan Islam di Indonesia. ${ }^{14}$

Dalam perkembangannya, model pendidikan Mambaul Ulum ini diikuti oleh beberapa pesantren lain di Indonesia, seperti Pesantren Tebuireng di Jombang, Pesantren Rejoso di Jombang, dan sedikit agak berbeda namun memiliki kesamaan pola adalah Pesantren Gontor di Ponorogo.

Perkembangan lebih jauh di alam pendidikan modern, berkaitan dengan kurikulum dan materi yang diajarkan di pesantren biasanya memiliki bebarapa model pendidikan. Pertama; pesantren yang menyelenggarakan pendidikan formal dengan menerapkan kurikulum nasional. Kedua; pesantren yang menyelenggarakan pendidikan keagamaan dalam bentuk madrasah dan mengajarkan ilmu-ilmu umum tetapi tidak menggunakan kurikulum nasional seperti Pondok Pesantren Gontor. Ketiga; pesantren yang hanya mengajarkan ilmu-ilmu agama dalam bentuk Madrasah Diniyah seperti yang dilakukan Pesantren Lirboyo, Kediri. Keempat; pesantren yang hanya sekedar tempat pengajian.

Kurikulum yang dipakai Mambaul Ulum berbeda dengan kurikulum pesantren pada umumnya. Dengan kata lain, Mambaul Ulum tidak hanya mengajarkan ilmu-ilmu agama, namun juga mengajarkan ilmu-ilmu lain seperti bahasa Belanda, membaca, menulis, berhitung, ilmu bumi, sejarah, ilmu alam, olahraga, bahasa Melayu dan Jawa serta pekerjaan tangan. Dalam hal ini, Darsiti Soeratman mengungkapkan: "Berdasarkan kurikulum, muridmurid sekolah agama itu, selain menerima pelajaran tentang agama Islam, juga bahasa Jawa, bahasa Melayu, berhitung, ilmu kodrat, dan beberapa mata pelajaran lainnya" ${ }^{15}$ Inilah yang

\footnotetext{
12 Andi Haris Prabawa, Atika Sabardila,"Peran Abdi Dalem Ngulama Keraton Kasunanan Surakarta", Surakarta: Lembaga Penelitian UMS, Jurnal Penelitian Humaniora Vol.2.No.1 Februari 2001, hlm. 4.

${ }^{13}$ Skripsi Siti Nuryati, Mambaul Ulum dalam Peningkatan Pengamalan dan Syiar Islam, Dinamika Pendidikan Islam dalam Mencetak Ulama di Surakarta Tahun 1905-1945, Fakultas Sastra dan Seni Rupa Universitas Sebelas Maret, 2010, hlm. 92.

14 Karel A. Steenbrink, Pesantren Madrasah dan Sekolah, Pendidikan Islam dalam Kurun Modern, Jakarta: LP3ES, 1994, Cet. 2, hlm. 36.

${ }^{15}$ Darsiti Soeratman, Kehidupan, Yogyakarta: Taman Siswa, 1989, hlm. 102
} 
menjadi ciri khas lahirnya Madrasah Mambaul Ulum dan proses perubahan dari tradisi pendidikan pesantren menjadi pendidikan madrasah.

Mambaul Ulum juga melahirkan tokoh-tokoh nasional seperti Prof. Dr. Notonegoro untuk mendalami falsafah negara, Prof. Dr. Soepomo untuk mendalami pembukaan UUD 1945, Jenderal Jatikusumo untuk mendalami strategi militer dan Prof. Poerbocaroko untuk mendalami kebudayaan. Di antara tokoh-tokoh lain yang merupakan alumni Mambaul Ulum adalah KHR. Moh Adnan, KH. Jauhar, KH. Prof. A Kahar Mudzakir, Brigjen Moh. Bahrun (mantan Pandam VII Diponegoro), KH. Saifudin Zuhri dan KH. Munawir Syadzali, MA, mantan Menteri Agama RI.

Perkembangan syi'ar pada masa Pakubuwono X berkembang dengan pesat terutama setelah berdirinya Madrasah Mambaul Ulum. Hal ini ditandai pembukaan pengajianpengajian di masjid-masjid yang dilakukan oleh alumni Mambaul Ulum. Melihat latar belakang berdirinya sekolah Mambaul Ulum, maka sangat penting untuk menggali lebih jauh tentang apa peran Pakubuwono X dalam pengembangan dakwah Islam di Surakarta tahun 1893-1939?. Tahun 1893 sampai tahun 1939 mengacu masa kekuasaan Pakubuwana X, dimana berbagai dinamika terjadi di tengah-tengah masyarakat Surakarta.

\section{METODE PENELITIAN}

Penelitian ini berjenis penelitian kualitatif, yaitu penelitian yang bermaksud untuk memahami fenomena tentang apa yang dialami oleh subyek penelitian misalnya perilaku, persepsi, motivasi, tindakan, dan lain-lain, secara holistik dan dengan cara deskripsi yang dalam bentuk kata-kata dan bahasa, pada konteks khusus yang alamiah dan dengan memanfaatkan berbagai metode alamiah. ${ }^{16}$

Dalam kontek ini, peneliti mencoba menelaah berbagai fenomena yang terjadi pada masa kekuasaan Pakubuwana $\mathrm{X}$ termasuk setting sosial politik pada masa itu dan berbagai fenomena terkait untuk memahami berbagai dinamika keagamaan dalam masa pemerintahannya.

Penelitian ini bersifat deskriptif yaitu suatu metode dalam meneliti status sekelompok manusia, suatu obyek, suatu set kondisi, suatu sistem pemikiran ataupun suatu kelas peristiwa pada masa sekarang. ${ }^{17}$ Tujuannya untuk membuat deskripsi, gambaran atau lukisan secara sistematis, faktual dan akurat mengenai fakta-fakta, sifat-sifat serta hubungan antar fenomena yang diselidiki. ${ }^{18}$

Dari berbagai literatur literatur kepustakaan, referensi, ensiklopedi, dokumen atau berbagai tulisan yang berkaitan dengan tema peneliti mencoba untuk mendeskripsikan peran Pakubuwana X dalam pengembangan dakwah Islam di Surakarta pada tahun 1893-1939. Faktor-faktor terkait yang menunjukkan peran dan pengembangan dakwah pada masa kekuasaannya serta indikator-indikator yang ada. Sedangkan tahun tersebut mengacu pada kekuasaan Pakubuwana X. Kemudian data yang ada tersebut di analisis sebagai upaya untuk bekerja dengan data, mengorganisasikan data, memilah-milahnya menjadi satuan yang dapat dikelola, mensintesiskannya, mencari dan menemukan pola, menemukan apa yang penting dan apa yang dipelajari dan memutuskan apa yang dapat diceritakan kepada orang lain. ${ }^{19}$

\footnotetext{
${ }^{16}$ Lexy J Moleong, Metodologi Penelitian Kualitatif, Bandung: Rosdakarya, 2014, cet. 32, hlm. 6.

${ }^{17}$ Moh. Nasir, Metode Penelitian, Jakarta: Ghalia Indonesia, 1988, cet., hlm. 63.

${ }^{18}$ Ibid, hlm. 63.

${ }^{19}$ Lexy J Moleong, Metodologi Penelitian Kualitatif,, hlm. 248.
} 
Dari data yang didapatkan, penulis mencoba untuk menganalisis peran Pakubuwana X dalam pengembangan dakwah Islam di Surakarta tahun 1893-1939. Dari analisis tersebut nantinya dapat diambil kesimpulan seberapa besar peran yang dilakukan oleh Pakubuwana $\mathrm{X}$ dalam pengembangan dakwah Islam di Surakarta pada tahun 1893-1939 dan apa saja peran yang dilakukan tersebut.

\section{PEMBAHASAN}

\section{Kondisi Sosial Politik Saat Pakubuwana X Berkuasa}

Pakubuwana X berkuasa pada masa penjajahan Belanda. Pamor keraton Surakarta Hadiningrat menyusut drastis karena cengkeraman Belanda yang begitu kuat. Gerak gerik raja sangat diawasi ketat oleh Belanda. Sekalipun berkuasa di keraton dan wilayahnya, ia bukanlah orang yang merdeka sepenuhnya. Surat-surat dari dan ke luar harus lewat residen ${ }^{20}$, meskipun hanya untuk urusan keluarganya.

Sebagai raja yang memiliki kedudukan tidak bebas dan menjadi 'tawanan' Belanda, tidak menghalangi dirinya untuk melakukan perlawanan terhadap Belanda dengan meletakkan simbol-simbol perlawanan. Diantaranya adalah penolakannya terhadap rumah sakit zending, perjalanan 'ke luar negeri' yang dapat membangkitkan nasionalisme, dan pengiriman orang untuk menziarahi makam Pakubuwana VI yang dibuang di Ambon. ${ }^{21}$

Di antara indikasi perlawannya adalah Raja menginstruksikan supaya secara teratur semua berita diterjemahkan dari surat-surat kabar berbahasa Belanda De Locomotief di Semarang, bahwa ia menaruh perhatian yang khusus terhadap perkembangan Perang Dunia I. Residen mendapat kesan bahwa Raja bersimpati dengan pihak Jerman seperti halnya banyak orang Indonesia, terutama mereka yang bergabung dengan Sarekat Islam.

Pakubuwana $X$ terus mengadakan perjalanan ke daerah-daerah sebagai simbol perlawanan terhadap Belanda, seperti ke daerah Semarang, Surabaya, Ambarawa dan Salatiga antara tahun 1903 dan 1906. Belanda hendak membatasai perjalanan tersebut dengan alasan biaya, namun sebenarnya lebih untuk membatasi kepopuleran Pakubuwana X.

Sekalipun perjalanan tersebut bersifat incognito $^{22}$, tetapi Pakubuwana $\mathrm{X}$ selalu mengesankan raja tertinggi di Pulau Jawa. Perjalanan tersebut diiringi pasukan yang besar serta dengan penghormatan dan upacara yang megah. Apalagi, setelah perjalannnya pada tahun 1922 bersamaan dengan peningkatnya semangat perlawanan terhadap Belanda. Pada tahun 1923 Pakubuwana X tidak melakukan perjalanan, tetapi pada tahun berikutnya melakukan perjalanan ke Malang. ${ }^{23}$

Pakubuwana X memiliki darah perlawanan dari kakeknya, Pakubuwana VI yang mendukung perjuangan Pangeran Diponegoro dan tidak mau bekerjasama dengan Belanda. Pakubuwana VI dinggap sebagai raja yang 'mbalelo' dan memberontak sehingga diasingkan di Ambon dan akhirnya mati ditembak, walaupun kematiannya dikhabarkan karena sakit,

\footnotetext{
${ }^{20}$ Residen adalah gelar dari sejumlah pejabat yang mewakili negaranya dengan status diplomatik, dengan pangkat yang rendah di Barat, atau di sebuah protektorat atau wilayah colonial. (lihat: https://id.wikipedia.org/wiki/Residen diakses 15 April 2021 jam.7.02.)

21 Pada tahun 1907 dan 1915 Pakubuwana X memerintahkan seseorang untuk mengunjungi makam kakeknya Pakubuwana VI yang diasingkan dan ditembak mati di Ambon. Pemerintah Hindia Belanda tidak bisa berbuat apa-apa, karena semua itu adalah konsekuensi dari simbol-simbol raja. Lihat; Kuntowijoyo, Raja Priyayi, hlm. 22.

${ }^{22}$ Incognito dalam Kamus Besar Bahasa Indonesia diartikan sebagai perjalanan secara tidak resmi (tidak dikenal); dengan menyamar sebagai orang kebanyakan; dengan menyembunyikan identitas. Lihat: https://kbbi.web.id/inkognito, diakses 15 April 2021.

${ }^{23}$ George D. Larson, Masa Menjelang Revolusi, Keraton dan Kehidupan Politik di Surakarta 1912-1942, terj. Dr. A.B. Lapian, Yogyakarta: Gadjah Mada University Press, 1990, hlm. 9.
} 
namun ketika kuburannya dipindahkan dari Ambon ke pemakaman raja-raja di Imogiri, pada tengkorak dahinya ditemukan berlobang, bekas tembus peluru.

Karena kondisi sosial politik tersebut, Pakubuwana X sangat berhati-hati dalam perlawanan terhadap Belanda agar tidak ditangkap dan diasingkan, termasuk caranya dalam mendukung pergerakan Nasional. Ia memiliki cara sendiri dalam menghadapi Belanda yang mendekte dan mengaturnya dengan ketat. Ia mengambil jalan tengah, mengikuti dan seolah kompromi dengan Kolonial Belanda, tetapi tetap menegakkan wibawanya sebagai Raja Jawa yang besar dan dihormati. ${ }^{24}$

2. Pakubuwana X Mendirikan Madrasah Mambaul Ulum dan Membuka Kembali Pesantren Jamsaren

Pakubuwana X menaruh perhatian yang besar terhadap keislaman rakyatnya. Hal ini dikarenakan jumlah kyai yang mengajar di langgar-langgar dan pondok-pondok pesantren sangat sedikit. Di antara bentuk kepedulian tersebut adalah dengan mendirikan Madrasah Mambaul Ulum pada tanggal 23 Juli 1905 bertempat di Pawestren Masjid Agung Surakarta. Berdirinya madrasah tersebut dengan harapan, alumninya akan dijadikan guru agama yang mampu mengajarkan agama di lembaga-lembaga pemerintahan, masjid maupun di tengahtengah masyarakat.

Karena pentingnya sekolah tersebut, maka sekolah agama ini didirikan di setiap masjid di Kabupaten. Dan sejak tahun 1919 pembiayaan sekolah-sekolah agama dimasukkan dalam rancangan anggaran Belanja kerajaan Surakarta. Sementara sebagian besar muridmuridnya adalah anak-anak abdi dalem Pamethakan (golongan agama). ${ }^{25}$

Pembukaan Madrasah Mambaul Ulum oleh Pakubuwana X mendapat respon besar umat Islam. Hal ini terbukti dengan banyaknya umat Islam yang belajar di Mambaul Ulum. Untuk mengatasi tersebut dibukalah kelas sore sekitar tahun 1925. Sehingga jumlah murid pagi dan sore kurang lebih 700 siswa.

Di berbagai kabupaten wilayah kekuasaannya, Pakubuwana $\mathrm{X}$ juga membuka Madrasah Mambaul Ulum sampai kelas IV. Setelah tamat, mereka melanjutkan sekolah Mambaul Ulum di Surakarta. Di antara kabupaten yang dibuka sekolah Mambaul Ulum tersebut adalah Klaten, Sragen, Boyolali, Wonogiri, Surakarta, Kartasura dan Sukoharjo. ${ }^{26}$

Melalui Kyai Idris, Pakubuwana X memerintahkan untuk menghidupkan kembali Pesantren Jamsaren. Kyai Idris ini pula sebagai pengelola Madrasah Mambaul Ulum, yang kelak dalam perjalanan sejarah, banyak lahir tokoh-tokoh besar dari pesantren tersebut seperti Kyai Mansyur pendiri Pondok Pesantren Al Mansyur Klaten, Kyai Dimyati pendiri Pondok Pesantren Termas Pacitan, Kyai Zarkasyi pendiri Pondok Pesantren Gontor Ponorogo dan lainnya. ${ }^{27}$

Pondok Pesantren Jamsaren dijadikan sebagai asrama siswanya, mengingat jumlah santrinya semakin banyak. Pesantren Jamsaren nampak hidup kembali pada masa Pakubuwana X, dimana siswa-siswanya ketika pagi bersekolah di Mambaul Ulum, maka sore harinya mereka berada di asrama yaitu Pondok Pesantren Jamsaren. Apalagi Kepala Mambaul Ulum, Kyai Idris juga sebagai pengasuh Pondok Pesantren Jamsaren.

\footnotetext{
${ }^{24}$ George D. Larson, Masa Menjelang Revolusi, Keraton dan Kehidupan Politik di Surakarta 1912-1942, hlm. 33.

${ }^{25}$ Darsiti Soeratman, Kehidupan Dunia Kraton Surakarta 1830-1939, Yogyakarta: Taman Siswa, 1989, hlm. 102.

${ }^{26}$ Siti Nurhayati, Manbaul Ulum Dalam Peningkatan Pengamalan dan Syiar Islam, Dinamika Pendidikan Islam Dalam Mencetak Ulama di Surakarta Tahun 1905-1945, Fakultas Sastra dan Seni Rupa UNS, 2010, hlm125.

${ }^{27}$ Purwadi, Sri Susuhunan Pakubuwana X: Perjuangan, Jasa dan Pengabdiannya untuk Nusa Bangsa, $2009: 142$.
} 
Pembukaan pesantren Jamsaren menjadi spirit baru bagi pendidikan Islam di Surakarta. Apalagi, setelah hampir lebih dari 75 tahun (1830 - 1905) vakum tidak ada aktivitas pembelajaran setelah para kyai dan muridnya terlibat dalam perang Diponegoro. Pembukaan Pesantren selain menjadi spirit bangkitnya pendidikan Islam di Surakarta khususnya, sekaligus memompa semangat belajar agama Islam di Surakarta.

Pesaantren Jamsaren adalah pesantren tertua di tanah Jawa. Secara umum, sejarah berdirinya melalui dua fase. Fase pertama adalah sekitar tahun 1750 M. Pada fase ini, Surakarta dipimpin oleh Pakubuwana IV yang bergelar Sunan Wali. Kondisi masyarakat Surakarta saat itu masih dipenuhi dengan adat istiadat Hindhu dan aliran-aliran animisme. Berbagai kemaksiatan dan kejahatan merajalela di berbagai kampung dan desa di Surakarta.

Untuk mengatasi tersebut, Pakubuwana IV mendatangkan para ulama di Surakarta. Di antara para ulama yang didatangkan tersebut adalah Kyai Jamsari dari Banyumas, yang kemudian setelah berada di Surakarta di tempatkan di barat daya dari istana Surakarta.

Kyai Jamsari mendirikan masjid, surau dan mengajarkan agama Islam seperti ilmu tauhid, bacaan Al Qur'an, syari'at Islam kepada masyarakat umum, para bangsawan dan para pejabat istana. Ajaran-ajaran tersebut dapat diterima dengan baik dan akhirnya berkembang ke berbagai daerah di Surakarta dan sekitarnya. Kampung kediaman Kyai Jamsari akhirnya dikenal dengan kampung Jamsaren -sampai sekarang-. Sementara kemaksiatan, kejahatan di Surakarta berkurang yang menjadikan Surakarta aman dan sejarahtera. Keadaan tersebut berjalan sampai Kyai Jamsari wafat dan digantikan putranya Kyai Jamsari II. ${ }^{28}$

Kyai Jamsari II juga keluar bersama santri-santrinya untuk ikut Perang Diponegoro, setelah itu keberadaannya tidak ditemukan. Semenjak itu, pesantren Jamsaren kosong dan tidak terurus sampai datangnya Kyai Idris ${ }^{29}$ dan semakin ramai dan berjalan kembali pada masa Pakubuwana X dengan didirikannya Mambaul Ulum.

3. Perhatian Pakubuwana X terhadap Dakwah Islam

Di daerah-daerah Pakubuwana $X$ mendirikan masjid. Masjid-masjid ini berfungsi selain sebagai tempat ibadah, juga sebagai tempat peringatan hari besar Islam, masjid-masjid tersebut digunakan untuk mengajarkan baca tulis Al Qur'an kepada umat Islam di wilayah Surakarta. Di antara masjid-masjid yang didirikan pada masa Pakubuwana $\mathrm{X}$ adalah di lingkungan keraton didirikan masjid Pudjosono, sementara diluar keraton didirikan masjid Suronatan, Pengging, Boyolali, Manang, Kedung Gudel dan Langenharjo. ${ }^{30}$

Pendidikan bagi abdi dalem Pamethakan dan keturunannya terus dididik untuk memahami Islam. Hasil pendidikan tersebut dijadikan standar sebagai perilaku anggota masyarakat yang lain. Para abdi dalem tersebut kemudian menjadi sumber daya dalam semua aktivitas keagamaan yang diadakan di dalam keraton. Mereka juga berfungsi sebagai individu-individu yang menjadi teladan dalam perilakunya bagi masyarakat secara luas. ${ }^{31}$

Tafsir Anom V yang menjadi ulama Keraton menjadi guru spiritual Pakubuwana X yang bertugas mengajarkan dan memberi pengetahuan tentang agama Islam. Pada masa Pakubuwana X, syiar Islam berkembang dengan baik. Di antara upaya tersebut adalah mengadakan pengajian secara rutin setiap tanggal 15 bulan Purnama (Qomariyah). Pengajian

\footnotetext{
${ }^{28}$ KH. Ali Darokah, Pondok Pesantren Jamsaren Solo dalam Historis dan Esensinya, Sala: Ramadhani, 1983, hlm. 2.

${ }^{29}$ Kyai Idris yang meneruskan Pondok Pesantren Jamsaren setelah Vakum sekitar 50 tahun. Ia berasal dari Klaten, keturunan Kyai Imam Rozi, bekas seorang pembantu Pangeran Diponegoro. Lihat: KH. Ali Darokah, Pondok Pesantren Jamsaren Solo dalam Historis dan Esensinya, Sala: Ramadhani, 1983, hlm. 3.

${ }^{30}$ H.A. Basit Adnan, Sejarah Masjid Agung dan Gamelan Sekaten di Surakarta, Surakarta: Yayasan Mardikintoko, 1996, hlm. 23

${ }^{31}$ Siti Nurhayati, hlm. 137-138.
} 
tersebut diisi oleh para ulama yang didatangkan dari berbagai daerah. Berbagai hasil ceramah dari berbagai ulama tersebut kemudian ditulis dan dijadikan sebagai majalah yang kemudian dibagikan kepada jamaah pengajian selanjutnya. Majalah tersebut diberi nama Hudaya yang berarti petunjuk dari Allah. ${ }^{32}$

Disisi lain, ijazah yang dikeluarkan Mambaul Ulum menjadikan kualitas lulusannya sebagai tolak ukur kecakapan para ulama keraton saat itu, baik secara keilmuan maupun secara akhlak. Mereka yang mengajarkan Islam di tengah-tengah masyarakat Surakarta. Mereka pula yang gigih menyebarkan Islam sampai ke rumah-rumah masyarakat.

Di antara pendidikan yang aktivitas pengajarannya dikembangkan di rumah-rumah adalah yang dilakukan oleh alumni Mambaul Ulum dan Pesantren Jamsaren. Di antara lulusannya tercatat sebagai pemimpin masyarakat, guru madrasah, kyai pesantren, pejabat pemerintah, penghulu hakim, kepala pengadilan agama, pejabat-pejabat tinggi dalam kementrian dan lainnya. ${ }^{33}$

Tafsir Anom V membuka sekolah-sekolah agama, baik di rumah sendiri atau di langgar. Tafsir Anom V juga membuka di pendopo rumahnya serta mendirikan bangunan sekolah di sebelah timur rumahnya (sekarang TK NDM Kauman). Saat itu, sekolah hanya untuk kaum dhuafa yang berkeinginan untuk belajar.

Kesadaran belajar dan beragama tinggi. Hal ini tidak lepas dari lulusan-lulusan Mambaul Ulum yang menghasilkan lulusan yang memadai dan mampu mengembangkan anak didiknya dengan ilmu yang diperolehnya. Mereka ahli membaca, mensyarah kitab-kitab fiqh, tafsir, hadits, tauhid, nahwu dan shorof. Penguasaan terhadap kitab-kitab tersebut menjadikan murid-muridnya mampu menangkap semangat ajaran Islam secara menyeluruh yang kemudian dikembangkan sendiri masing-masing alumni tersebut. ${ }^{34}$

\section{Pada Masa Pakubuwana X, Syi'ar Keislaman Meningkat}

Berkat kesadaran penguasaan ilmu agama yang baik berdampak terhadap tumbuhnya kesadaran masyarakat dalam beragama cukup tinggi. Para alumi mampu menangkap semangat ajaran Islam, memiliki akhlak yang baik, dan mampu memahami bahkan pengajaran yang diperolehnya bukan sekedar sebagai ilmu pengetahuan, tetapi untuk diamalkan. Mereka memahami dengan penguasaannya terhadap kitab-kitab tersebut akan mempertinggi akhlak serta rasa taat dan taqwa kepada Allah SWT. ${ }^{35}$

Kualitas lulusan yang baik tersebut menjadikan mereka mudah diterima masyarakat untuk mengajarkan Islam di tengah-tengah mereka. Bahkan masyarakat memberikan penghargaan yang tinggi. Tidak sedikit di antara mereka yang mendirikan lembaga-lembaga pendidikan seperti pondok pesantren, menjadi mubaligh, guru dan penyuluh agama.

Siti Nurhayati mengutip pendapat Cliffor Geertz dalam 'Santri dan Abangan di Jawa' menyebutkan bahwa kesadaran pendidikan agama di Surakarta pada masa Pakubuwana X menunjukkan semakin kuatnya ciri keagamaan Islam. Norma-norma kesetiaan sangat ditekankan, hasil-hasil kesusastraan dan kebudayaan Islam diberikan dan diajarkan kepada rakyatnya. Keraton Kasunanan sebagai pusat pemerintahan bagi keraton, berawal dari dalam keratan rakyat dapat mengikuti berbagai kegiatan keagamaan. Penghulu Keraton mengajarkan shalat, puasa, serta menjalankan rukun Islam, kewajiban untuk mengislamkan

\footnotetext{
${ }^{32}$ Ibid, hlm. 138.

${ }^{33}$ Siti Nurhayati, hlm. 139.

34 Moh. Ardani, Peran Karaton Dalam Pengembangan Budaya dan Pendidikan Islam, Disampaikan dalam Seminar Nasional 'Peran Karaton dalam Pengembangan Islam', Rabu 17 Januari 2007 di Sasana Ondrowino Karaton Kasunanan Surakarta Hadiningrat, kerjasama UMS dengan Karaton Kasunanan Surakarta Hadiningrat, hlm. 26.

${ }^{35}$ Muh. Ardani, hlm. 26.
} 
anak laki-laki dan pendidikan tentang agama. Kondisi keagamaan pada masa ini berkembangan dan maju. Dengan berlandaskan Al Qur'an dan Hadits, para ulama menyusun syari'at yang merupakan hukum Islam. ${ }^{36}$

Pakubuwana X juga memerintahkan agar khutbah Jum'at diterjemahkan ke dalam bahasa Jawa dan Arab yang sebelumnya khutbah Jum'at memakai bahasa Arab. Hal ini dimulai pada tanggal 27 Sura tahun Dal 1832 Jawa. Dipasang pula pengeras suara, dan langsung disiarkan oleh radio SRI (Siaran Radio Indonesia) milik Kasunanan dengan penyiar terkenal saat itu R.M. Moelyadi Joyomartono. ${ }^{37}$

Pengajian-pengajian digalakkan. Di antaranya adalah pengajian secara rutin setiap tanggal 15 bulan Purnama (Qomariyah). Pengajian tersebut diisi oleh para ulama yang didatangkan dari berbagai daerah. Berbagai hasil ceramah dari berbagai ulama tersebut kemudian ditulis dan dijadikan sebagai majalah yang kemudian dibagikan kepada jamaah pengajian selanjutnya. Majalah tersebut diberi nama Hudaya yang berarti petunjuk dari Allah. ${ }^{38}$

Secara otomatis, kemajuan pendidikan berdampak langsung terhadap semaraknya syiar Islam di wilayah Surakarta. Masjid-masjid ramai orang-orang belajar belajar membaca Al Qur'an. Guru-guru lulusan Mambaul Ulum dan Pesantren Jamsaren dianggap mumpuni untuk mengajarkan ilmu agama, sehingga mereka menjadi kepercayaan masyarakat untuk menjawab berbagai problem keagamaan yang timbul.

Pengaruh lain adalah mulai tumbuh pusat-pusat penyebar dan dakwah Islam di Surakarta. Salah satunya adalah Kauman menjadi pusat ulama yang berperan sebagai juru dakwah dan penyebaran Islam. Hal ini dibuktikan dengan berbagai kegiatan keagamaan seperti pengajian, sekolah Islam dan acara-acara besar Islam di Kauman sampai tahun 1930 terus berlangsung dan masih eksis. Kegiatan pengajian diselenggarakan ulama-ulama lulusan Mambaul Ulum yang berlangsung di Kauman seperti pengajian di Langgar Winongan, Langgar Gontoran dan Langgar Sememen. ${ }^{39}$

Di kota-kota dan desa-desa di Surakarta mengalami perkembangan dalam pengamalan Islam. Hal ini terlihat dari peningkatan jumlah orang shalat berjamaah di Masjid Agung, misalnya shalat Jum'at, Dhuhur dan Ashar jumlah jamaah semakin ramai.

Peningkatan jamaah karena adanya daya tarik murid-murid yang belajar di Madrasah Mambaul Ulum yang melaksanakan shalat jamaah di Masjid Agung pada waktu Dhuhur dan Ashar. Hal ini mendorong masyarakat untuk mengikuti shalat berjamaah di masjid tersebut. ${ }^{40}$

Di antara peningkatan syiar Islam lainnya adalah dengan perubahan cara berdakwah dan khutbah Jum'at. Pakubuwana X memerintahkan agar khutbah Jum'at diterjemahkan ke dalam bahasa Jawa dan Arab yang sebelumnya khutbah Jum'at memakai bahasa Arab. Hal ini dimulai pada tanggal 27 Sura tahun Dal 1832 Jawa. Dipasang pula pengeras suara, dan langsung disiarkan oleh radio SRI (Siaran Radio Indonesia) milik Kasunanan Surakarta dengan penyiar terkenal saat itu R.M. Moelyadi Joyomartono. ${ }^{41}$

Dengan harapan penduduk yang masih memeluk kepercayaan dan beridentitas abangan, diislamkan dan diajak mengunjungi Masjid Agung untuk beribadah. Strategi yang ditempuh adalah raja meminta kepada ulama yang tergabung dalam birokrasi Reh Pangulon

\footnotetext{
${ }^{36}$ Siti Nuryati, hlm. 67

${ }^{37}$ H.A. Basit Adnan, Sejarah Masjid Agung dan Gamelan Sekaten di Surakarta, Surakarta: Yayasan

Mardikintoko, 1996, hlm. 15.

${ }^{38}$ Siti Nurhayati, hlm. 138.

${ }^{39}$ Ibid, hlm. 144

${ }^{40}$ Ibid, hlm. 147

41 H.A. Basit Adnan, Sejarah Masjid Agung dan Gamelan Sekaten di Surakarta, Surakarta: YayasanMardikintoko, 1996, hlm. 15.
} 
untuk berkhutbah dengan bahasa Jawa dan Arab. Reh Pangulon adalah lembaga yang berfungsi mengurusi administrasi keagamaan secara integratif di bawah pimpinan penghulu Tafsir Anom. Para pengawai pembantu lembaga Reh Pangulon disebut sebagai abdi dalempamethakan yang berarti golongn putih (suci). ${ }^{42}$

\section{KESIMPULAN}

Berdasarkan analisis terhadap Peran Pakubuwana X Terhadap Pengembangan Dakwah Islam di Surakarta Tahun 1893-1939, maka dapat disimpulkan bahwa Pakubuwana X memiliki peran yang besar terhadap pengembangan dakwah Islam di Surakarta tahun 18931939.

Hal tersebut didasarkan bahwa kehadiran Madrasah Mambaul Ulum yang didirikan Pakubuwa $\mathrm{X}$ berpengaruh terhadap pengembangan dakwah Islam dengan hadirnya para ulama, guru agama, pejabat keagamaan. Kehadiran ulama dan guru agama berpengaruh secara langsung terhadap berkembangnya dakwah dan syi'ar Islam di Surakarta dan sekitarnya.

Keberadaan Madrasah Mambaul Ulum dan Pesantren Jamsaren sangat berpengaruh terhadap tokoh-tokoh keagamaan. Lulusan Mambaul Ulum dan Jamsaren mampu menduduki jabatan-jabatan strategis, sebagai guru agama, penyuluh keagamaan maupun pemegang jabatan di Keraton Surakarta. Di antara klasifikasi lulusan berkaitan dengan jabatan yang dipengang adala jabatan modin atau jajar, penghulu naib, penghulu agama Kabupaten atau Penghulu Pengadilan Negeri (Landraad).

Para lulusan Madrasah Mambaul Ulum diberi pangkat 'priyayi'. Namun demikian mereka tetap memiliki sifat merakyat, taat, taqwa dan ramah. Tak jarang mereka juga berfungsi sebagai penghulu, kyai, mubaligh dan guru agama. Tak jarang pula mereka sebagai penghubung yang menjembatani hubungan antara pemerintah Kasunanan dengan masyarakat Islam.

Pengaruh lain adalah semakin maraknya perkembangan syiar Islam di Surakata dimana Kauman menjadi pusat kegiatan Islam. Hal ini dibuktikan dengan berbagai kegiatan keagamaan seperti pengajian, sekolah Islam dan acara-acara besar Islam di Kauman sampai tahun 1930 terus berlangsung dan masih eksis. Kegiatan pengajian diselenggarakan ulamaulama lulusan Madrasah Mambaul Ulum yang berlangsung di Kauman seperti pengajian di Langgar Winongan, Langgar Gontoran dan Langgar Sememen.

Di kota-kota dan desa-desa di Surakarta mengalami perkembangan dalam pengamalan Islam. Hal ini terlihat dari peningkatan jumlah orang shalat berjamaah di Masjid Agung, misalnya shalat Jum'at, Dhuhur dan Ashar jumlah jamaah semakin ramai. Peningkatan jamaah karena adanya daya tarik murid-murid yang belajar di Madrasah Mambaul Ulum yang melaksanakan shalat jamaah di Masjid Agung pada waktu Dhuhur dan Ashar. Hal ini mendorong masyarakat untuk mengikuti shalat berjamaah di masjid tersebut.

\footnotetext{
${ }^{42}$ Sejarah masjid Agung Surakarta, Surakarta; Pengurus Masjid Agung Surakarta, 2014, hlm. 45.
} 


\section{DAFTAR PUSTAKA}

Adnan, H.A. Basit, Sejarah Masjid Agung dan Gamelan Sekaten di Surakarta, Surakarta: Yayasan Mardikintoko, 1996.

Andi Haris Prabawa, Atika Sabardila, "Peran Abdi Dalem Ngulama Keraton Kasunanan Surakarta", Surakarta: Lembaga Penelitian UMS, Jurnal Penelitian Humaniora Vol.2.No.1 Februari 2001.

Darokah, Ali, KH., Pondok Pesantren Jamsaren Solo dalam Historis dan Esensinya, Sala: Ramadhani, 1983.

Kuntowidjoyo, Raja Priyayi Dan Kawula, (cet. 2), Yogyakarta: Ombak, 2006.

Larson, George D., Masa Menjelang Revolusi, Keraton dan Kehidupan Politik di Surakarta 1912-1942, terj. Dr. A.B. Lapian, Yogyakarta: Gadjah Mada University Press, 1990.

Moh. Ardani, Peran Karaton Dalam Pengembangan Budaya dan Pendidikan Islam, Disampaikan dalam Seminar Nasional 'Peran Karaton dalam Pengembangan Islam', Rabu 17 Januari 2007 di Sasana Ondrowino Karaton Kasunanan Surakarta Hadiningrat, kerjasama Universitas Muhammadiyah Surakarta dengan Karaton Kasunanan Surakarta Hadiningrat. (makalah)

Moleong, Lexy J, Metodologi Penelitian Kualitatif, Bandung: Rosdakarya, 2014, cet. 32.

Nasir, Moh., Metode Penelitian, Jakarta: Ghalia Indonesia, 1988.

Pengurus Masjid Agung, Sejarah masjid Agung Surakarta, Surakarta; Team Masjid Agung Surakarta, 2014.

Purwadi, et.al., Sri Susuhunan Paku Buwono X, Perjuangan, Jasa dan Pengabdiannya untuk Nusa Bangsa, Jakarta; Bangun Bangsa, 2009.

Siti Nurhayati, Mambaul Ulum dalam Peningkatan Pengamalan dan Syiar Islam, Dinamika Pendidikan Islam dalam Mencetak Ulama di Surakarta Tahun (1905-1945), Surakarta: UNS, 2010. (Skripsi)

Soebahar, Abd.Halim, KebijakanPendidikan Islam dari Ordonansi Guru sampai UU Sisdiknas, Jakarta: Rajagrafindo, 2013.

Soeratman, Darsiti, Kehidupan Dunia Kraton Surakarta 1830 - 1939, Yogyakarta: Taman Siswa, 1989.

Steenbrink, Karel A., Pesantren Madrasah dan Sekolah, Pendidikan Islam dalam Kurun Modern, Jakarta: LP3ES, 1994, Cet. 2.

Subhan, Arief, Lembaga Pendidikan Islam Indonesia Abad ke-20, Jakarta: UIN Jakarta, 2009.

Sumodiningrat, Gunawan dan Ari Wulandari, Paku Buwono X, 46 Tahun Berkuasa di Tanah Jawa, Yogyakarta: Narasi, 2014.

Surat Snouck Hurgrounje kepada Tuan Lindenborn, surat kiriman dalam de Nieuwe Roterdamsche Courant tanggal 20 Mei 1915. (Kumpulan Karangan Snouck Hurgronje $X$, Jakarta: INIS, 1994). 
36 Mamba'ul 'Ulum, Vol. 17, No. 1, April 2021:24-36

https://www.antaranews.com/berita/141197/lima-alasan-paku-buwono-X-itu-pahlawan. di akses 15 April 2021.

http://www.kerajaannusantara.com/id/surakarta-hadiningrat/news/401-Sri-Susuhunan-

Pakubuwono-X-Mendapat-Gelar-Pahlawan-Nasional, di akses tanggal 15 April 2021.

https://kbbi.web.id/zending, di akses tanggal 15 April 2021.

https://id.wikipedia.org/wiki/Residen, diakses 15 April 2021.

https://kbbi.web.id/inkognito, diakses 15 April 2021. 